\title{
Occurrence of Mycoplasma hyopneumoniae in slaughter pigs from Southern Brazil
}

\section{Ocorrência de Mycoplasma hyopneumoniae em amostras de pulmão de suínos obtidas de frigorífico do sul do Brasil}

\author{
Violetta Dias Pacce ${ }^{1}$, Natasha Rodrigues de Oliveira ${ }^{1}$, Sérgio Jorge ${ }^{1}$, Odir Antônio Dellagostin ${ }^{1}$ \\ ${ }^{1}$ Universidade Federal de Pelotas, Centro de Desenvolvimento Tecnológico, Núcleo de Biotecnologia, Campus Universitário Capão do Leão, \\ Pelotas - RS, Brazil
}

\begin{abstract}
Mycoplasma hyopneumoniae is the causative agent of enzootic pneumonia (EP), a disease that is highly prevalent and globally distributed, causing significant economic losses to the swine industry. Disease progression is characterized by reduced feed conversion and the development of lung lesions. Considering the limited information about the epidemiology of EP in Southern Brazil, the main objective of this study was to determine the occurrence of M. hyopneumoniae in swine lung samples and to evaluate the scores of lung lesions caused by local strains. A total of 120 samples was randomly collected and processed. DNA was extracted from lung tissue to perform nested-PCR and lungs were inspected to evaluate the presence of the pneumonia-like gross lesions of M. hyopneumoniae. The results showed $95.8 \%$ positive samples, while the lung lesion score analysis showed suggestive lesions in $60 \%$ of samples. The detection of positive samples in nested-PCR was associated with the presence of pneumonia-like gross lesions $(\mathrm{P}<0.01)$. The results demonstrate a high occurrence of EP in slaughter pigs from southern Brazil.
\end{abstract}

Keywords: Diagnosis. Enzootic Pneumonia. Nested-PCR.

\section{RESUMO}

O Mycoplasma hyopneumoniae é o agente causador da Pneumonia Enzoótica Suína (PES), doença altamente prevalente e mundialmente distribuída, causando grandes perdas econômicas para a indústria suinícola. A progressão da doença é caracterizada pela redução das taxas de conversão alimentar e o desenvolvimento de lesões pulmonares. Visto que há informação limitada sobre a epidemiologia da PES no sul do Brasil, o objetivo do presente trabalho foi determinar a prevalência de $M$. hyopneumoniae em amostras de pulmão suíno e avaliar o score de lesões pulmonares causadas pelas cepas locais. Um total de 120 amostras foram coletadas aleatoriamente, processadas e analisadas. O DNA foi extraído do tecido pulmonar para realização de Nested-PCR e os pulmões foram inspecionados para presença de lesões macroscópicas sugestivas de M. hyopneumoniae. Os resultados demonstraram 95,8\% das amostras positivas para o patógeno. A análise do score pulmonar mostrou lesões sugestivas da PES em $60 \%$ das amostras. A detecção de amostras positivas no Nested-PCR foi associada com a presença de lesões sugestivas $(\mathrm{P}<0.01)$. Os dados obtidos neste trabalho demonstram a alta prevalência da PES em granjas do RS.

Palavras-chave: Diagnóstico. Pneumonia Enzóotica Suína. Nested-PCR.

\section{Correspondence to:}

Odir Antônio Dellagostin

Universidade Federal de Pelotas, Centro de Desenvolvimento Tecnológico, Núcleo de Biotecnologia, Campus Universitário Capão do Leão, Pelotas - RS, Brazil

Campus Universitário Capão do Leão, CP 354

CEP: 96010-900, Pelotas - RS, Brazil

e-mail: sergiojorgevet@hotmail.com

Submited: September 04, 2018

Approved: February 04, 2019
How to cite: Pacce VD, Oliveira NR, Jorge S, Dellagostin OA. Occurrence of Mycoplasma hyopneumoniae in slaughter pigs from Southern Brazil. Braz J Vet Res Anim Sci. 2019;56(1):e150072. https://doi.org/10.11606/issn.16784456.bjvras.2019.150072

\section{Introduction}

Mycoplasma hyopneumoniae is the etiological agent of enzootic pneumonia (EP) in pigs, a widespread respiratory disease that results in significant economic losses, mainly 
due to the high susceptibility of the affected animals to other respiratory pathogens (Maes et al., 2018). The bacterium colonizes the ciliated epithelial cells of the respiratory tract, damaging the cells, which predisposes infected animals to secondary infections. The disease is characterized by a non-productive cough, reduction of growth rates, reduced feed conversion efficiency, weight loss, high morbidity and low mortality (Sibila et al., 2009).

EP is highly prevalent (65\%-93.6\%) and distributed in almost every swine production area in the world (Fablet et al., 2012; Beilage et al., 2009). M. hyopneumoniae is typically introduced into pig herds by purchase of sub-clinically infected animals or through airborne transmission between herds (Otake et al., 2010; Sibila et al., 2009). The disease shows different degrees of severity occurring from acute to chronic, and its development is influenced by various factors, including strain virulence, number of microorganisms and secondary infections (Sibila et al., 2009). In affected animals, macroscopic lung lesions are observed, which consist of purple to grey consolidated areas affecting the apical and middle lobes and, eventually, the cranial part of the diaphragmatic lobes (Garcia-Morante et al., 2016). If there is a simultaneous bacterial infection, animals can present more severe lung lesions with larger parts of tissue affected (Thacker \& Minion, 2012).

M. hyopneumoniae recovery from clinical samples is laborious. Given the organism's fastidious characteristic and slow growth rate, isolation is not used for routine diagnosis and prevalence studies. Alternatively, several diagnostic techniques can be used to monitor M. hyopneumoniae infections (Simionatto et al., 2013). PCR assays are the most sensitive and specific and can be used with a variety of samples. Nested-PCR is widely used to upgrade diagnosis sensitivity, as it involves the use of two primer sets specific to the $16 \mathrm{~S}$ ribosomal RNA gene of M. hyopneumoniae (Calsamiglia et al., 1999). Since epidemiology data on EP infection in southern Brazil are limited, the aim of this study is to determine the occurrence of $M$. hyopneumoniae in lung samples through nested-PCR and compare this with the presence of lung lesions caused by local strains.

\section{Material and methods}

One hundred-twenty lung samples taken from growing pigs originating in farms located in the cities Horizontina ( $27^{\circ} 37^{\prime} 44.28^{\prime \prime}$ south latitude and $54^{\circ} 18^{\prime} 39.61^{\prime \prime}$ west longitude) and São Pedro do Butiá (28 $7^{\prime}$ '28.07” south latitude and $54^{\circ} 53^{\prime} 36.13^{\prime \prime}$ west longitude) from Rio Grande do Sul state were recovered randomly at a slaughterhouse.
This study area is endemic for respiratory diseases in swine. DNA was extracted with a Wizard ${ }^{\circ}$ Genomic DNA Purification (Promega) kit. PCR reactions were carried out using two pairs of primers from the $16 \mathrm{~S}$ ribosomal DNA previously described by Calsamiglia et al. (1999). These primers amplify a $649 \mathrm{bp}$ region on the first reaction and an intern region of $352 \mathrm{bp}$ on the second. Amplifications were performed in a final volume of $25 \mu \mathrm{l}$ using the following conditions: 30 cycles of $95{ }^{\circ} \mathrm{C}$ for $30 \mathrm{sec}, 60^{\circ} \mathrm{C}$ for $45 \mathrm{sec}$ and $72^{\circ} \mathrm{C}$ for $30 \mathrm{sec}$. For each amplification, negative (ultrapure water) and positive (M. hyopneumoniae 7448 strain) controls were added. A total of $5 \mu$ of each PCR reaction was separated by electrophoresis in a $1 \%$ agarose gel, subsequently stained by ethidium bromide. The gels were viewed and photographed under UV light.

Lung lesion analysis was performed in the slaughterhouse and scored for pneumonia-like gross lesions following the method described by Hannan et al. (1982). This method consists of a bi-dimensional approach, represented by a diagram, using lung lobes as parameters. The number of triangles affected per lobe is multiplied by five and divided by the number of triangles in each pulmonary lobe. The score for each lobe is summed up to obtain the total lung score. This could reach a maximum of 35 points. M. hyopneumoniae-like gross lung lesions were defined macroscopically as purple to grey areas of pulmonary consolidation, generally located on the cranio-ventral parts of the lung lobes. The relationship between the presence/absence of M. hyopneumoniae and the presence/absence of pneumonia-like gross lesions was analyzed with the chi-squared test using IBM SPSS Statistics software version 16.0.1. Values of $\mathrm{P}<0.01$ were defined as statistically significant.

\section{Results and discussion}

Nested-PCR reactions yielded a detectable DNA fragment of $352 \mathrm{bp}$ (data not shown). M. hyopneumoniae DNA was detected in 115/120 (95.8\%) of swine lungs. Positive lung lesion scores were observed in 72/120 (60\%) of samples (Table 1). The mean of positive scores was 3.21 (SD 2.95), the lowest score was 0.26 and the highest was 16.93 (Table 2).

Table 1 - Nested-PCR and lung lesion scores results

\begin{tabular}{cccc}
\hline Samples & Nested-PCR (\%) & Score (\%)* & Mean \pm SD** \\
\hline Positive & $115(95.8)$ & $72(60)$ & $3.21 \pm 2.95$ \\
Negative & $5(4.2)$ & $48(40)$ & - \\
Total & $120(100)$ & $120(100)$ & - \\
\hline
\end{tabular}

*Number of lung samples and its representation in percentage. **Mean + Standard deviation (SD) of lesion scores according to Hannan et al. (1982), where values vary from 0 (no lesions) to 35 (whole lung affected) 
Table 2 - Histopathological scores (0 - 20) of positive samples by nested-PCR

\begin{tabular}{cc}
\hline Scores* $^{*}$ & Positive samples \\
\hline 0 & 45 \\
$0,2-5$ & 63 \\
$6-10$ & 4 \\
$11-20$ & 3 \\
Total & 115 \\
\hline
\end{tabular}

*Lung scores were divided in groups by different score ranges $(0 ; 0.2$ to $5 ; 6$ to $10 ; 11$ to 20$)$

Samples with positive scores (higher than zero) were also positive for M. hyopneumoniae through nested-PCR, with the exception of one sample Table 1 . The detection of $M$. hyopneumoniae DNA in the lung was associated with the presence of EP-like gross lesions $(\mathrm{P}<0.01)$.

In this study, the use of nested-PCR in post-mortem samples showed high levels of $M$. hyopneumoniae detection, which reinforces its applicability to evaluate the etiological agent presence. Makhanon et al. (2012) used pulmonary tissue from slaughter pigs as samples and found a 77.4\% M. hyopneumoniae prevalence. According to the authors, this type of sample is the most reliable for the molecular diagnosis of slaughter pigs that are convalescent and pathogen carriers.

In pulmonary score analysis, $60 \%$ of samples showed pneumonia-like gross lesions of EP. Only one of those was not positive for the pathogen using nested-PCR. On the other hand, some positive samples in nested-PCR did not present a lung lesion score. This result might be because of the natural process of cicatrization, whereby the microorganism remains in the respiratory tract, turning the animal into an asymptomatic pathogen carrier (Pulgarón et al., 2015; Siqueira et al., 2017). Moreover, the detection of M. hyopneumoniae in lungs without macroscopic pneumonia-like lesions may also be related to the infectious process. In these cases, the use of molecular methods such as nested-PCR is a useful tool because it is capable of detecting low quantities of microorganism per sample (Calsamiglia et al., 1999), which would be considered false negatives by less sensitive methods.

A high prevalence of $M$. hyopneumoniae in swine herds has been reported, reaching 93.6\% (Fablet et al., 2012; Makhanon et al., 2012). The presence of this microorganism in endemically infected areas might be influenced by management practices and the housing conditions of animals, considering that transmission through the airway frequently occurs between closed regions (Sibila et al., 2009). In Brazil, data on the infection's prevalence is limited.
According to Vicente et al. (2013), 52\% of samples collected from different farms in a central region of São Paulo state were seropositive for M. hyopneumoniae. Silva et al. (2009) also detected this agent in $52.6 \%$ of lung samples collected from southeast Brazil. Moreover, specific data on prevalence per country are not available in the literature, as the disease is not considered obligatory to report and does not limit commercial trade (Maes et al., 2018).

A recent study demonstrated that the severity of lesions in slaughter pigs is significantly higher where different strains of M. hyopneumoniae were found, indicating the importance of genetic diversity on the herd level (Michiels et al., 2017). In the present work, the occurrence of $M$. hyopneumoniae was determined from lung tissue samples obtained from different regions of Rio Grande do Sul state. Pathogen detection associated with the identification of EP pneumonia-like gross lesions indicates the presence of virulent circulating strains in these herds.

\section{Conclusion}

Given the need for an improved understanding of porcine mycoplasma occurrence, molecular diagnosis is a valuable tool to detect the M. hyopneumoniae presence in slaughter pigs. In combination with clinical signs, nested-PCR provides a useful method to differentiate convalescent animals from healthy carriers. Further, the genotyping of M. hyopneumoniae strains will allow the monitoring of the presence and diversity of this pathogen in slaughter pigs from southern Brazil.

\section{Conflict of interest}

None of the authors of this paper has a financial or personal relationship with other people or organizations that could inappropriately influence or bias the content of the paper.

\section{Ethics Statement}

The study was performed with samples from a slaughterhouse located in the city of Pelotas, Rio Grande do Sul state, after obtaining the approval of the Ethical Committee for Animal Experiments of the Universidade Federal de Pelotas (approval number 5614).

\section{Acknowledgements}

This work was supported by Coordenação de Aperfeiçoamento de Pessoal de Nível Superior (CAPES) and Conselho Nacional de Desenvolvimento Científico e Tecnológico (CNPq). 


\section{References}

Beilage EG, Rohde N, Krieter J. Seroprevalence and risk factors associated with seropositivity in sows from 67 herds in north-west Germany infected with Mycoplasma hyopneumoniae. Prev Vet Med. 2009;88(4):255-63. http:// dx.doi.org/10.1016/j.prevetmed.2008.10.005. PMid:19101052.

Calsamiglia M, Pijoan C, Trigo A. Application of a nested polymerase chain reaction assay to detect Mycoplasma hyopneumoniae from nasal swabs. J Vet Diagn Invest. 1999;11(3):246-51. http://dx.doi. org/10.1177/104063879901100307. PMid:10353356.

Fablet C, Marois-Créhan C, Simon G, Grasland B, Jestin A, Kobisch M, Madec F, Rose N. Infectious agents associated with respiratory diseases in 125 farrow-tofinish pig herds: a cross-sectional study. Vet Microbiol. 2012;157(1-2):152-63. http://dx.doi.org/10.1016/j. vetmic.2011.12.015. PMid:22226820.

Garcia-Morante B, Segalés J, Fraile L, Pérez de Rozas A, Maiti H, Coll T, Sibila M. Assessment of Mycoplasma hyopneumoniae-induced pneumonia using different lung lesion scoring systems: a comparative review. J Comp Pathol. 2016;154(2-3):125-34. http://dx.doi.org/10.1016/j. jcpa.2015.11.003. PMid:26774274.

Hannan PC, Bhogal BS, Fish JP. Tylosin tartrate and tiamutilin effects on experimental piglet pneumonia induced with pneumonic pig lung homogenate containing mycoplasmas, bacteria and viruses. Res Vet Sci. 1982;33(1):76-88. http:// dx.doi.org/10.1016/S0034-5288(18)32364-6. PMid:7134653.

Maes D, Sibila M, Kuhnert P, Segalés J, Haesebrouck F, Pieters M. Update on Mycoplasma hyopneumoniae infections in pigs: knowledge gaps for improved disease control. Transbound Emerg Dis. 2018;65(Suppl 1):110-24. PMid:28834294. https://doi.org/10.1111/tbed.12677.

Makhanon M, Tummaruk P, Thongkamkoon $\mathrm{P}$, Thanawongnuwech R, Prapasarakul N. Comparison of detection procedures of Mycoplasma hyopneumoniae, Mycoplasma hyosynoviae, and Mycoplasma hyorhinis in lungs, tonsils, and synovial fluid of slaughtered pigs and their distributions in Thailand. Trop Anim Health Prod. 2012;44(2):313-8. http://dx.doi.org/10.1007/s11250-0110022-z. PMid:22116666.

Michiels A, Vranckx K, Piepers S, Del Pozo Sacristán R, Arsenakis I, Boyen F, Haesebrouck F, Maes D. Impact of diversity of Mycoplasma hyopneumoniae strains on lung lesions in slaughter pigs. Vet Res. 2017;48(1):2. http:// dx.doi.org/10.1186/s13567-016-0408-z. PMid:28095890.

Otake S, Dee S, Corzo C, Oliveira S, Deen J. Long-distance airborne transport of infectious PRRSV and Mycoplasma hyopneumoniae from a swine population infected with multiple viral variants. Vet Microbiol. 2010;145(3-4):198208. http://dx.doi.org/10.1016/j.vetmic.2010.03.028. PMid:20418029.

Pulgarón YB, Marques LM, Campos ACA, Rodriguez JP, Márquez OP, Ortiz AD, Rivero EL, Timenetsky J. Detection, quantification and genetic variability of Mycoplasma hyopneumoniae from apparently healthy and pneumonic swine. Braz J Vet Res Anim Sci. 2015;52(4):310. http:// dx.doi.org/10.11606/issn.1678-4456.v52i4p310-318.

Sibila M, Pieters M, Molitor T, Maes D, Haesebrouck F, Segalés J. Current perspectives on the diagnosis and epidemiology of Mycoplasma hyopneumoniae infection. Vet J. 2009;181(3):221-31. http://dx.doi.org/10.1016/j. tvjl.2008.02.020. PMid:18396428.

Silva FMF, Castro LA, Silva A Jr, Moraes MP, Moreira MAS, Almeida MR. Detection of Mycoplasma hyopneumoniae in lungs and nasal swabs of pigs by nested PCR. Arq Bras Med Vet Zootec. 2009;61(1):149-55. http://dx.doi.org/10.1590/ S0102-09352009000100021.

Simionatto S, Marchioro SB, Maes D, Dellagostin OA. Mycoplasma hyopneumoniae: from disease to vaccine development. Vet Microbiol. 2013;165(3-4):234-42. http:// dx.doi.org/10.1016/j.vetmic.2013.04.019. PMid:23680109.

Siqueira FM, Pérez-Wohlfeil E, Carvalho FM, Trelles O, Schrank IS, Vasconcelos ATR, Zaha A. Microbiome overview in swine lungs. PLoS One. 2017;12(7):1-21. PMid:28719637. https://doi.org/10.1371/journal.pone.0181503.

Thacker EL, Minion FC. Mycoplasmosis. In: Zimmerman JJ, Karriker LA, Ramirez A, Schwarz KJ, Stevenson GW, editors. Diseases of swine. 10th ed. Ames: Wiley-Blackwell; 2012. p. 779-98.

Vicente AF, Catto D, Allendorf SD, Garcia KCOD, Antunes JMAP, Appolinario CM, Peres MG, Megid J. Soropositividade para Mycoplasma hyopneumoniae em suínos abatidos em frigoríficos da região central do estado de São Paulo. Arq Bras Med Vet Zootec. 2013;65(6):1899-903. http://dx.doi. org/10.1590/S0102-09352013000600045. 
Financial Support: Financial support was provided by Coordenação de Aperfeiçoamento de Pessoal de Nível Superior (CAPES) and Conselho Nacional de Desenvolvimento Científico e Tecnológico (CNPq).
Authors Contributions: V.P. and N.O. carried out the experiment. V.P. wrote the manuscript with support from N.O and S.J. S.J. helped supervise the project. O.A. conceived the original idea and supervised the project. 